one perfect insect, however, emerged on September 1, 1941, from those pupæ which were collected. Atissa pygmcea was seen on frequent occasions during later visits to the pit, but it was never found in any great numbers.

From the observations here recorded it is interesting to note that the insects found in such an unpromising environment are all members of the Diptera. In this connexion it is perhaps well to repeat the statement made by Thorpe" that "the Diptera are not only able to support life in media of an osmotic pressure that is rapidly fatal to most other insects, but that they have also a greater power of adaptation to changes in concentration than have other orders".

In concluding this brief account of the insects inhabiting the brine-pit, mention should perhaps be made of those insects which from time to time have been discovered in the pit water but do not actually breed in the brine. On several occasions the hemipteron Corixa (species undetermined) was observed to visit the pit and swim for short periods in the water. On August 31, 1941, the beetle llybius fuliginosus $\mathrm{F}$. was captured while swimming in the water. On June 21, 1942, an unidentified Hydrobius larva was taken when collecting water samples.

It is a pleasure to record here my acknowledgement of the assistance given by Mr. Riley, Mr. Coe and Mr. Donisthorpe of the British Museum, and of Mr. H. Britten of Manchester, in the identification of the insects found. I wish also to thank Mrs. Kay of Brine-pits Farm, Malpas, for permission granted to visit the pit; and finally to my wife for help in collecting.

'Sherlock, Mem. Geol. Survey, Mineral Resources of Great Britain, Rocksalt and Brine, 18, 54 (1921).

- Ormerod, G. W., Quart. J. Geol. Soc., 4, 269 (1848).

"Ward, H. B., and Whipple, G. C., "Fresh-water Biology", 80 (1918).

"Carpenter, K. E., "Life in Inland Waters", 228 (1928).

"Thorpe, W. H., Trans. S.E. Union Sci. Soc., 27-34 (1927).

Thorpe, W. H., Trans. Entom. Soc. Lond., 78, 331 (1930).

'Thorpe, W. H., The Pan-Pacific Entomologist, 7, 145 (1981).

\section{WAR-TIME TRANSPORT IN GREAT BRITAIN}

$\mathrm{T}$ HE Fifteenth Report of the Select Committee on National Expenditure demonstrates the vital importance of transport to the war effort of Great Britain. That bad transport is one of the main causes of absenteeism and lost time in production has been emphasized from time to time in the Select Committee's earlier reports, and the evidence received during the last six months led the Committee to make a special investigation into this problem from the side of the Ministry of War Transport and the transport undertakings. While this aspect of the problem is fairly generally appreciated, it is intimately if not inseparably linked with that of passenger transport generally, and the full extent of the repercussions of the rubber and petrol situation are very far from being realized by the general public.

The evidence submitted to the Select Committee indicates that there are few, if any, services running which are not essential. The recent restrictions on the use of motor-cars in Great Britain render buses more than ever necessary for meeting the needs of the general public. Even in non-industrial areas, there is already a shortage, and there, as elsewhere, intending passengers are frequently left behind. The priority system is only partly effective in securing the transport of industrial workers. It is open to abuse, and the practical impossibility of distinguishing between essential and non-essential passengers is one of the first factors in the situation to which regard must be paid.

The second factor, which is by no means fully recognized, is the effect which transport restrictions have already had on industrial efficiency. There is a serious handicap, for example, on management, because it is no longer possible to choose the quickest and most efficient means of transport. Economy in petrol often means waste in man-hours. Moreover, not only is output affected in the factories if workers and management cannot arrive in time but also, as the Select Committee points out, the morale of the country will be affected if the housewife cannot do her shopping or if her child cannot get to and from school. It might well be added that workers in the larger towns, with their longer hours in a heavily polluted atmosphere, will suffer in health and their work in efficiency if transport restrictions deprive them entirely of access to fresh air and the countryside. No long-term policy of planning the war, such as we should now be pursuing, can safely disregard such considerations, and the severer the limitations of transport the more essential it becomes to plan their use to the maximum extent.

Transport, in fact, oecupies a key place not only in the production of munitions, but also in the daily life of every man, woman and child in Great Britain. The vital importance of transport must be kept constantly in mind when questions of priority of labour and materials are decided. Indeed, the Select Committee is not merely concerned with the fair and efficient use of existing facilities ; it also gives frank warning that it may well be essential to increase those facilities, and reference is made in particular to provision for the manufacture of buses and spare parts and for the supply of fuel and tyres.

What emerges from this survey is the importance of securing full co-operation between the transport services themselves and the general public which uses those services. One of the major difficulties is the labour shortage, which is aggravated by a high percentage of absenteeism among women workers, and the Ministry is criticized for its neglect to make any serious effort to ascertain the causes of such absenteeism.

Many of the Committee's suggestions are on points of practical detail. In regard to the difficult question of staggering hours in shops or factories, it recommends the establishment of local transport consultative committees in all areas and the introduction of schemes for internal or general staggering of factory hours. When such schemes are being worked out, the factories affected should be grouped roughly according to the "priority of their products, so that some attempt may be made to allot the best time to the most important factories. Regional commissioners in all regions should make orders enforcing the early closing of shops in the central shopping sites of large cities, so that both shop-workers and customers can be got home before the rush of factory workers begins, and employers should, where necessary, make arrangements that their employees get reasonable shopping facilities during these restricted times. Similarly, it is recommended that except in emergency, factory hours should not be altered without first considering the transport problems 
involved, and the local transport consultative committees should be fully used for such purposes.

If, however, the public themselves are to help to improve the transport services of Great Britain, much greater publicity must be given to the reasons for transport difficulties. "Transport goes to War", recently issued by the Ministry of Information, makes a beginning although the emphasis is rather excessively on the blitz conditions and effects : what is wanted is something to grip the public imagination and secure their support and sympathy under everyday war-time conditions. Moreover, any appeal for the co-operation of the public, such as the Select Committee suggests, must be based not merely on a fuller understanding of the difficulties of the transport services themselves, but also on a sympathetic appreciation of the position and difficulties of the travelling public. The importance of diverting more traffic from the roads to the railways is stressed, and it is recommended that where adequate railway facilities are available for any particular factory or group of factories, special bus facilities should not be provided. Similarly, the natural tendency for people to rush for the last bus which gets thern to their work at the right time requires correction by individual response, but apart from an examination by the Ministry of Labour of the possibility of reducing cross-travelling between one town and another by directing workers to places nearer their homes, it may well be doubted whether there is much unnecessary travelling by train on the part of the general public, at least over distances of any extent. It is clear from this report that the point has been reached, if not passed, when a further reduction in travelling facilities, whether by bus or rail, is likely to be a false economy, and to impair the war effort to an extent more rather than less serious, because the waste of time, of labour or of health that results may be indirect and cumulative rather than immediately obvious.

\section{FORTHCOMING EVENTS}

(Meetings marked with an asterisk are open to the public)

Saturday, November 21

Roxal Photographic Society (Scientimc and Technicat Grotp) (at 16 Princes Gate, South Kensington, London, S.W.7), at 2.30 p.m.Symposium on "Industrial Radiography".

\section{Monday, November 23}

ROYAI, SOCIETY OF ARTS (at John Adam Street, Adelph1, London, W.C.2), at 1.45 p.m,-Mr. A. C. Pallot : "Some Aspects of Insulation", 1. "Thermal Insuiation at Medium Temperatures-The Insulation of Pipes and Structures" (Cantor Lectures, 1).

BRITISH COUNCIL, ROYAL ASIATIC SOCIETY, EAST INDIA ASSOOLATION AND THE INDIA SOCIETY (at the Royal Society, Burlington House Piccadilly, London, W.1), at 3 p.m.-Mr. Laurence Bingon: Fourth Centenary of the Mughai Akbar.

ROYAL GEOORAPHIOAL SOOIETY (at Kensington Gore, London, S.W.7), at 5 p.m.-Kodachrome Film: "Halifax to Victoria B.C." Commentary by Mr. C. W. Stokes.

\section{Tuesday, November 24}

Chadwiok Pubeio Leoture (in the Sir Edward Meyerstein Lecture Theatre, Westminster Hospital Medical School, 17 Horseferry Road, London, S.W.11, at 2.30 p.m. Sir Arthur MacNalty, K.C.B.: "The Prevention of Tuberculosis in Peace and War".

ROYAL INSTITUTION (at 21 Albemarle Street, Irondon, W.1), at 3 p.m.-Prof. J. C. Drummond : "The History of our More Important Foods", (i) Bread."

INSTTTUTION OF CTVIL ENGINERRS (ROAD ENGINEERING DIVISION) (at Great George Street, Westminster, London, S.W.1) at 5.30 p.m.-
Mr. A. H. D. Markwick and Mr. H. S. Keep: Bases for Roads and Aerodromes using Local Aggregates and Soils" Agsociation of ScIENTIYTO WoRkERS (at the Royal Photographic Society, 16 Princes Gate, South Kensington, London, S.W.7), at 6.30 p.m.- Projection of the Cine Films entered for the Exhibition of "Photography in Science and Industry".
Wednesday, November 25

INSTIrUTE of PhYsics (ELgONRONIOS Group) (at the Royal Institution, Albemarle Street, London, W.1), at 3 p.m.-Mr. G. T. Winch : "Photo Cells and their Applications",

Friday, November 27

ROYAL INSTTPUTION (at 21 Albemarle Street, London, W.1), at 5 p.m.-Mr. Frank Twyman, F.R.S.: "Interferometry in the Optical Workshop".

NORTH-EAst COAgT INSTTTUTION OF ENGINEERS AND SHIPBUILDFRS (in the Lecture Theatre of the Mining Institute, Newcastle-upon-Tyne). at 6 p.m.- Mr. R. C. Thompson and Mr. Harry Hunter: "The British (Andrew Laing Lecture).

\section{Saturday, November 28}

RoYal PHotograpHIC SOCIETY (at 16 Princes Gate, South Kensington, London, S.W.7), at 3 p.m.-Dr. S. O. Rawing: "Sensitometry since Hurter and Driffeld" (Hurter and Driffield Memorial Lecture).

\section{APPOINTMENTS VACANT}

APPLICATIONS are invited for the following appointments on of before the dates mentioned:

Lecturgr in Exaineering SubJects-The Principal, Kingston Technical College, Kingston, Surrey (November 28).

Visiting Mathemarcics Lromuren-The Principal, Froebel Educational Institute, Knebworth House, Knebworth, Herts (December 1).

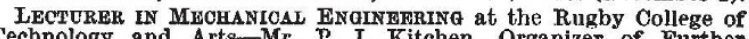
Technology and Arts-Mr. P. I. Kitchen, Organizer of Further Education, Rugby (December 2),

INSTRUCTOR IN BEEKEEPING-The Education Officer, County Hall, Wakefield (December 14).

REarus Profmssor of Grorogr at Edinburgh University-The Private Secretary, Scottish Office, Fielden House, 10 Great College Street, London, S.W.1 (January i1).

assistant Techntcian in the Pathologioar Departarent-The Superintendent, Grimsby and District General Hospital, Grimsby.

\section{REPORTS and other PUBLICATIONS}

\author{
(not ineluded in the monthly Books Supplement)
}

\section{Great Britain and Ireland}

Department of Scientific and Industrial Research. Index to the Literature of Food Investigation. Vol. 13, No. 4, March, 1942. Compiled by Agnes Elizabeth Glennie, assisted by Catherine Alexander.

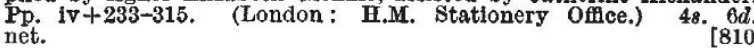

Agricultural Research Institute of Northern Ireland. Fifteenth Annual Report, 1941-42. Pp. 22. (Hillsborough, Co. Down : Agricultural Research Institute of Northern Ireland.) [810

Philosophical Transactions of the Royal Society of London. Series B : Biological Sciences. Vol. 231, No. 580: The Reproductive Cycles of the British and Continental Faces of the Starling. By Dr. W. S. Bullough. Pp. 165-246+ plates 12-21. 218. 6d. Vol. 231, No. 581: The Structure and Function of the Mouth-parts, Rostrum and Fore. gut of the Weevil Calandra granaria $\mathrm{L}$. By Dr. R. Rennell. Pp. 247gut of the Weevil Calandra granaria L. By Dr. R. Rennell. Pp. 247-
291. 78. (London: Cambridge University Press.) Proceedings of the Royal Society of Edinburgh, Series B : Biology, Proceedings of the Royal Society of Edinburgh, Series B: Biology,
Vol. 61, Part 3, No. 24: The Occurrence of Endodermis in Leguminous Root Nodules and its Effect upon Nodule Function. By Helen $\mathrm{L}$ Frazer. Pp. 328-343. 18. 3d. Vol. 61, Part 3, No. 25: Growth Stages in the Ammonite Promicroceras marstonense Spath. By Dr. Fthel D. Currie. Pp. 344-367. 28. Vol. 61, Part 4, No. 26: The Induction of Pregnancy in the Golden Hamster during the Breeding Pause. By Pregnancy in the Golden Hamster during the Breeding Pause, By
Dr. O. Peczenik. Pp, 368-374. 6d. (Edinburgh and London: Oliver
and Boyd.)
[910

$[910$

Sir Robert Kane, First President of Queen's College, Cork: a Pp. 43. (Cork : Cork University Press.) 2s. net. O. Raghallagh,

\section{Other Countries}

University of Illinois: Engineering Experiment Station. Bulletin No. 335: A Photoelastic Study of Stresses in Gear Tooth Fillets. By Prof. Thomas J. Dolan and Edward L. Broghamer. Pp. 44.45 cents Bulletin No. 336 : Moments in I-Beam Bridges. By Prof. Nathan M. Newmark and Chester P. Siess. Pp. 148, 1 dollar. Circular No 43: at the University of Illinois, May 21-23, 1941. Pp. 112. 50 cents Circular No. 44 : Combustion Efficiencies as related to Performance of Domestic Heating Plants. By Prof. Alonzo P. Kratz, Prof. Seich Konzo and Daniel W. Thomson. Pp. 30. 40 cents. (Urbana, Ill. University of Illinois.)

National Research Council. American Geophysical Union Transactions of 1942. Part 1: Reports and Papers, Joint Regional Meetings, Section of Hydrology (a) Dallas, Texas: (b) Pasadena, California.

Pp. 171. (Washington, D.C.: National Academy of Sciences.)
[1410 1.25 dollars.

Brooklyn Botanic Garden Record. Vol. 31, No. 3 : The Local Flora Section (Native Wild Flower Garden) of the Brooklyn Botanic Garden By Henry K. Svenson. (Guide No. 14.) Pp. 181-210. (Brooklyn,
N.Y.: Brooklyn Institute of Arts and Sciences.) 